\title{
Dietary Composition Independent of Weight Loss in the Management of Non-Alcoholic Fatty Liver Disease
}

\author{
Tannaz Eslamparast ${ }^{1}$, Puneeta Tandon ${ }^{1,2,+}$ and Maitreyi Raman ${ }^{3, *,+}$ \\ 1 Division of Gastroenterology, Department of Medicine, University of Alberta, Edmonton, AB T6G 2X8, \\ Canada; eslampar@ualberta.ca (T.E.); ptandon@ualberta.ca (P.T.) \\ 2 Cirrhosis Care Clinic and CEGIIR, University of Alberta, Edmonton, AB T6G 2X8, Canada \\ 3 Division of Gastroenterology, Department of Medicine, University of Calgary, Calgary, AB T6G 2X8, Canada \\ * Correspondence: mkothand@ucalgary.ca; Tel.: +1-403-592-5020 \\ + These authors contributed equally to this work.
}

Received: 23 June 2017; Accepted: 21 July 2017; Published: 26 July 2017

\begin{abstract}
Poor dietary composition is an important factor in the progression of non-alcoholic fatty liver disease (NAFLD). The majority of NAFLD patients follow diets with overconsumption of simple carbohydrates, total and saturated fat, with reduced intake of dietary fiber and omega-3 rich foods. Although lifestyle modifications including weight loss and exercise remain the keystone of NAFLD management, modifying dietary composition with or without a calorie-restricted diet may also be a feasible and sustainable strategy for NAFLD treatment. In the present review article, we highlight the potential therapeutic role of a "high quality healthy diet" to improve hepatic steatosis and metabolic dysfunction in patients with NAFLD, independent of caloric restriction and weight loss. We provide a literature review evaluating the evidence behind dietary components including fiber-, meat- and omega-3-rich diets and, pending further evidence, we concur with the EASL-EASD-EASO Clinical Guidelines recommendation of the Mediterranean diet as the diet of choice in these patients.
\end{abstract}

Keywords: non-alcoholic fatty liver disease; dietary composition; Mediterranean diet

\section{Introduction}

Non-alcoholic fatty liver disease (NAFLD) is one of the most common non-communicable diseases worldwide, affecting $25-30 \%$ of the global population, with the highest prevalence in the Middle East and South America. In North America and Europe, one-fourth of the adult population has NAFLD [1,2]. The major established risk factors for NAFLD include obesity, insulin resistance and dyslipidemia [3]. The NAFLD spectrum ranges from simple liver steatosis to hepatic necroinflammation called non-alcoholic steatohepatitis (NASH) with or without fibrosis. This may progress to advanced cirrhosis and hepatocellular carcinoma (HCC) [4,5]. NAFLD acts in synergy with related metabolic risk factors and other existing conditions to promote the development of HCC [6], and importantly, HCC can be seen in the absence of cirrhosis in this condition [7]. The burden of NAFLD continues to increase. It is the third leading cause of liver transplantation and, by 2030, it is predicted to become the most common reason for transplantation in the United States [8].

The majority of NAFLD patients overconsume fructose, red meat and saturated fat $[9,10]$. In addition they have reduced intake of dietary fiber and omega-3 rich food $[9,10]$. This pattern of dietary intake can lead to obesity and the metabolic syndrome, increasing the risk for NAFLD. In addition, there is emerging evidence that a deleterious dietary composition may predispose people to NAFLD, even in the absence of obesity [11,12].

Lifestyle modifications involving weight loss and exercise remain the cornerstone of NAFLD management [13]. Caloric restriction is the most important element in nutrition intervention for NAFLD 
patients and plays a critical role in visceral, subcutaneous and hepatic fat reduction, and weight loss [14]. Weight reduction of 3-5\% can cause a notable decrease in hepatic fat and improvement in insulin sensitivity [15]. However, weight loss and weight maintenance remain a considerable challenge for many individuals. Conceivably, modifying dietary composition with or without a calorie-restricted diet may be a feasible and sustainable strategy for NAFLD management. As such, the present review focuses on addressing the potential role for modifying dietary composition and dietary patterns in the management of NAFLD-interventions that may have efficacy with or without weight loss.

\section{Definition of NAFLD}

NAFLD is a hepatic manifestation of the metabolic syndrome [16]. It encompasses a broad pathological spectrum of disease characterized by excessive hepatic triacylglycerol (TAG) deposits in more than $5 \%$ of hepatocytes in patients with little or no history of alcohol consumption $[4,13]$.

\section{Pathophysiology of NAFLD}

The pathophysiology of NAFLD is complex and includes numerous genetic, dietary, metabolic and hormonal factors. In 1998, Day and James proposed the "2-hit hypothesis" [17] to explain the progression from steatosis to NASH. New insights suggest a multiple hit hypothesis, with the first hit of insulin resistance leading to increased fat accumulation within the hepatocyte. The steatotic liver is vulnerable to lipid peroxidation, impaired hepatocyte apoptosis and increased cytokine activity [17]. In addition, a complex interplay between multiple factors such as oxidative stress-mediated lipotoxicity, proinflammatory adipokines and mitochondrial dysfunction act in parallel with genetic predisposition to advance disease. Dietary carbohydrate $(\mathrm{CHO})$ intake and insulin resistance may inhibit the reduction of reactive oxygen species and represent potential additional hits in a susceptible individual [18]. This multiple hit theory provides a broader pathophysiologic view of NAFLD compared to the "two-hit" theory $[19,20]$.

\subsection{Lipid Metabolism}

Obesity and insulin resistance can result in an elevated free fatty acid (FFA) flux induced by dysregulation of de novo lipogenesis (DNL), lipolysis of visceral fat, and dietary fat. Increased hepatic FFA flux leads to excess fat deposition in hepatocytes with a large metabolic load and promote hepatocyte lipotoxicity and oxidative stress [21]. Ultimately, the additive effects of cytokines released by Kupffer cells and activation of the immune response and cell death pathways meditate the transition to NASH $[22,23]$.

\subsection{Glucose Metabolism}

$\mathrm{CHO}$ intake can also stimulate hepatic lipogenesis by converting excess glucose to fatty acids. Under normal conditions, insulin transports glucose into the cell to be stored as glycogen [24]. Hepatic steatosis occurs when impaired insulin signaling results in compensatory hyperinsulinemia. In this situation, glucose absorption decreases in skeletal muscle providing further substrate for DNL. Hyperinsulinemia also decreases glycogen synthesis, increases hepatic FFAs uptake, alters TAG transportation, and inhibits $\beta$-oxidation $[22,25]$.

\subsection{Gut Microbiome}

The gut microbiota has been implicated in obesity, diabetes, metabolic syndrome and NAFLD through effects on calorie salvage, host energy metabolism, proinflammatory signaling, and via direct hepatotoxicity of bacterial products [26]. Obese humans may have a fundamentally different gut microbiota, with decreased diversity, but increase in the representation of the phylum Firmutes and proportionate decrease in Bacteroidetes compared with lean individuals [27]. Microbes produce several hundred volatile organic compounds, including ethanol, of which the systemic effects are 
unknown [28]. Our group has previously shown that in obese patients with clinically suspected NAFLD, a significantly altered fecal volatile organic compound profile and compositional shift in the fecal microbiome is observed [29]. In this study, we were unable to replicate previous observations of phylum-level differences in the fecal microbiota. Additional study findings revealed that ester volatile organic compounds were identified more frequently in NAFLD compared to controls. Conceivable the volatile organic compounds are of bacterial origin, however, the role of diet in the genesis of volatile organic compounds cannot be excluded [30]. The gut-liver axis has a pivotal role in the development and progression of NAFLD [31]. Gut-derived lipopolysaccharides (LPS), a component of gram-negative bacteria induces liver injury by invoking a cascade of morphological, biochemical and functional changes such as insulin resistance, increased hepatic oxidative stress, acute inflammatory responses, metabolic deregulation and fibrosis [32,33]. Bacterial translocation is a process in which alterations in tight junction proteins reduce the intestinal barrier integrity, resulting in increased endotoxin absorption. In a healthy individual, these bacterial products are rapidly cleared by the hepatic immune system, but in an injured liver, they can result in the release of reactive oxygen metabolites, proteases and other degenerative enzymes, which worsen liver damage [34,35]. Over the last decade, increased gut permeability and elevated levels of LPS in the serum have been documented in NAFLD and NASH patients [36]. Gut dysbiosis therefore plays a role in the development and progression of liver damage and in the severity of NAFLD, NASH and their complications [37].

\subsection{Visceral Adipose Tissue vs. Subcutaneous Adipose Tissue (VAT: SAT)}

Adipose tissue is a complex, active endocrine organ. It contributes to the pathogenesis of NAFLD by modulating insulin sensitivity by secreting adipocytokines. Visceral fat tissue (VAT) is densely infiltrated with macrophages, promotes inflammation, stimulates proinflammatory cytokine secretion such as TNF- $\alpha$, and Interlukin-6 (IL-6), and inhibits insulin sensitivity of adipocytes [22]. Expression of TNF- $\alpha$ is greater in VAT compared to subcutaneous fat (SAT), and can trigger proinflammatory pathways [38], which disrupt insulin signaling and increase steatosis. Conversely, adiponectin, a protein hormone with anti-inflammatory properties, produced by adipocytes, has decreased secretion in VAT, leading to altered lipid metabolism and increased inflammation [22].

\section{Observations of Dietary Composition and Patterns in NAFLD}

\subsection{Calorie, Macronutrient Composition and Dietary Fiber}

The relationship between diet and the development of NAFLD is complex and extends beyond total energy intake. Assessment of total energy intake in patients with NAFLD compared with controls demonstrates discordant results. Although some investigators have shown higher energy intake in NAFLD compared to healthy controls [39], others have identified similar energy intake in both groups, with notable differences in dietary composition [40]. Cortez-Pinto and colleagues identified significantly lower protein and $\mathrm{CHO}$, and higher total fat and $n-6$ consumption in NAFLD patients compared to controls [40]. Musso et al. showed that patients with NASH compared to controls had non-significantly higher intake of total fat; in contrast, higher intake of saturated fat, and lower PUFA consumption was observed in NASH compared to controls [11]. Recently, Wehmeyer and colleagues found no differences in the consumption of fat between NAFLD patients and controls [39]. The divergent study results may arise due to heterogeneous patient populations (NAFLD vs. NASH) and/or varying dietary data capture tools.

Several studies have focused on the detrimental effects of high consumption of simple $\mathrm{CHO}$ on hepatic and metabolic functions in NAFLD [9,15]. Recently, a study observed a significantly higher glucose intake per $1000 \mathrm{kcal}$ in patients with NAFLD compared to controls [39]. In 2007, a group of investigators reported that simple $\mathrm{CHO}$ consumption, particularly from soft drinks, in subjects diagnosed with NAFLD was significantly greater than in subjects with a normal liver ( $23 \pm 42 \mathrm{vs.}$ $12 \pm 24 \mathrm{~g} /$ day, $p$-value $=0.03$ ). The result was sustained even after adjusting for sex, age, BMI and total 
calorie intake (OR $=1.45,95 \%$ CI 1.13-1.58) [10]. Volynets identified a higher intake of protein, total carbohydrates, monosaccharides and disaccharides compared with controls [41]. A study of 28 patients with NASH and 18 patients with simple steatosis supported that a diet rich in $\mathrm{CHO}$, particularly sweets and not cereals, was associated with higher risk of NASH compared to simple steatosis [42]. Although, this study found a significant association in both sexes, another study in 2015 reported that a high-CHO/sweet dietary pattern, characterized by high intakes of fruit, cakes, soft drinks and sugary snacks, was positively associated with risk of NAFLD only in females. They also showed that females in the highest quartile had a greater risk of developing NAFLD than those in lowest quartile, after adjustment for cofounding factors ( $\mathrm{OR}=2.19,95 \% \mathrm{CI} 1.4-3.46)$, while no association was observed in males [43]. These findings are consistent with the observation in the study by Tajitma et al. [44], who investigated the relationship between CHO intake and NAFLD prevalence in middle-aged Japanese.

Regarding the protein content of the diet, several studies have reported a significantly higher protein intake in patients with NAFLD compared to controls [10,39-41], while other studies found no difference [11,45]. In 2016, Kobayashi, et al. [46] compared the dietary intake of Japanese patients with NAFLD and T2D. Their results showed a significantly higher energy ratio from protein in NAFLD patients than in T2D $(p=0.008)$.

Poor fiber intake is common in NAFLD [39,40]. In a series of 25 NASH patients and 25 matched healthy controls, the mean daily fiber intake was almost $50 \%$ lower in NASH versus control patients (13 \pm 4 g vs. $23 \pm 8 \mathrm{~g}, p=0.0001$ ) [11]. This is supported by a subsequent study showing lower fiber intake in NAFLD patients as compared to controls [39]. In a study from Japan, patients with NAFLD had a lower vegetable intake and a higher consumption of fruits and sweets compared to T2D patients [46]. In 2016, Cheng and colleagues [45] assessed the relationship between dietary intake and hepatic lipid content in NAFLD, and showed that fiber intake was inversely associated with hepatic fat fraction and intrahepatic lipid.

Taken together, the macronutrient composition of the diet, particularly high independent consumption of $\mathrm{CHO}$, simple sugars, fat and protein, and low fiber intake may be associated with the risk of NAFLD, independent of energy overconsumption. The mechanism by which the intake of certain nutrients may influence the disease has not yet been completely understood.

\subsection{Meat (Red Meat vs. Other)}

High meat intake is associated with glucose intolerance, impaired insulin sensitivity, and may increase the risk of T2D [37,47]. Although T2D is accepted as a risk factor for NAFLD, there are no data investigating the direct association between intake of dietary protein sources and NAFLD. A recent cross-sectional study [10] showed that subjects with NAFLD consumed $27 \%$ more protein from all types of high and low fat meat (beef, liver, sausage, lamb, chicken and turkey) compared to subjects without NAFLD. Even after adjusting for sex-, age-, BMI- and total calorie intake-, a higher protein intake resulted in a higher risk of NAFLD. Interestingly, when the type of protein intake was considered, the intake of protein from fish high in omega-3 trended to decrease the risk of NAFLD (OR $=0.73,95 \%$ CI $0.52-1.04)$. Although, this study found no significant difference in the consumption of different types of meat and fats, another case-control study reported that the intake of red meat was significantly higher in NAFLD cases compared to controls [48]. Notably, in the latter study, the meat consumption in both study groups exceeded the recommendation level of Chinese Dietary Pagoda (75 g/day). Findings showed no significant differences in white meat consumption between NAFLD and control groups [48].

High intake of processed meat has also been associated with an increased risk of NAFLD. This may be linked to the high content of sodium, saturated and trans-fatty acids in these products [49,50].

There are several possible explanations for the potential role of red meat intake in NAFLD: (a) red meat is high in saturated fat and cholesterol; (b) presence of preservatives and additives in processed meat; (c) presence of other dietary factors with negative effects in individual with high meat intake, 
since they usually follow a "Western" dietary pattern, which has been linked to hypertension, diabetes, obesity and certain cancers $[47,51,52]$.

\subsection{Omega-3 Rich Diets}

Dietary sources of omega-3 PUFAs, especially eicosapentaenoic acid (EPA) and docosahexaenoic acid (DHA) are found in with highest concentration in seafood, mostly fatty fishes including pilchards, sardines, mackerel, trout, salmon, herring and tuna. Marine omega-3 PUFAs are also found in lean fish (haddock, cod, and crustaceans), shellfish, and fish oils with lower concentrations [53]. Omega-3 PUFAs are also found in certain vegetable oils such as flaxseed oil. Studies have associated a higher consumption of fish rich in omega-3 with a reduced risk of NAFLD [10]. This has been supported by case-control studies reporting a significantly lower concentration of omega-3 PUFA, especially DHA, in NAFLD patients than in healthy individuals [54-56]. There are few data concerning hepatic fatty acid composition in patients with NAFLD. In one study, NAFLD patients had a depletion of omega-3 PUFAs in hepatic TAG. The low level of circulating omega-3 PUFAs was associated with greater rates of lipogenesis and hepatic FFA flux along with a reduction in VLDL synthesis and $\beta$-oxidation, promoters of NAFLD to its necroinflammatory form, NASH [54]. Similarly, a study by Allard et al. [30] compared three groups of patients (NASH, elevated liver enzymes with minimal histological findings and patients with simple steatosis). They showed that NASH patients had a total PUFA intake below the recommended level and lower hepatic omega- 3 and omega- 6 compared to the other two groups. There were no differences in $n-6 / n-3$ ratio among the three study groups [30].

\section{Dietary Intervention on NAFLD Outcomes}

Lifestyle modification is the first-line treatment option, with weight loss via a hypocaloric diet being the most important therapeutic target in NAFLD [57]. There is evidence in support of particular diets, most notably the Mediterranean diet (Table A1) [58].

\subsection{Mediterranean Diet}

A "Mediterranean diet" (MD) is a dietary pattern originally inspired by the traditional diet in Mediterranean countries, characterized by a high consumption of plant-based foods, such as vegetables, fruits, whole grains, seeds, nuts and legumes, and moderate consumption of protein-source foods such as fish and poultry (Table 1). This diet is rich in monounsaturated fatty acids (MUFA) primarily from olive oil and olives, reduced fat dairy products and low red meat intake. It has proven beneficial effects on the prevention of cardiovascular disease, hypertension, hypercholesterolemia, and obesity $[59,60]$. In 2014, a small observational study explored the potential association between a Mediterranean diet and the presence and the severity of NAFLD. Kontogianni et al. [61] found that a greater adherence to the Mediterranean diet was significantly correlated with a lower degree of hepatic steatosis and insulin resistance in patients with biopsy-proven NASH compared to simple fatty liver. The MD score was negatively correlated with the serum alanine aminotransferase (ALT), insulin resistance index, and the severity of steatosis [61].

The Mediterranean diet has been shown to reduce hepatic fat and improve hepatic insulin sensitivity even without weight loss in NAFLD patients [62]. Adherence to Mediterranean diet has also been linked to less advanced NAFLD and a lower risk of having the metabolic syndrome in this patient population [58]. Two randomized trials have contributed the most to the evidence for a potential beneficial effect for the MD in NAFLD. In a randomized parallel-group design, 37 men and 8 women with T2D were assigned to a 28-week isocaloric diet (high $\mathrm{CHO} /$ high fiber or high MUFA). There was a greater decrease in hepatic steatosis in the MUFA compared to the high CHO diet (29\% vs. 4\%) [63]. Additionally, another randomized cross-over trial assessed the impact of a MD compared to a standard low-fat high-CHO in non-diabetic NAFLD patients. A significant reduction in hepatic steatosis was observed with the MD [64]. Accordingly, the MD has been recommended as the diet of choice for the treatment of NAFLD by the EASL-EASD-EASO Clinical Practice Guidelines $[13,65]$. There are multiple 
potential mechanisms for the observed benefits of the MD on the course of NAFLD. Extra-virgin olive oil (EVOO) is a frequently identified dietary component of the MD, containing over 30 phenolic compounds. Phenolic compounds are known to exhibit antioxidant properties [66]. In addition, EVOO has been shown to reduce postprandial blood glucose levels and LDL potentially mediated through glucagon like peptide 1 upregulation [65]. Through various mechanisms, $n-3$ fatty acids in fish oil have been shown to reduce hepatic lipid accumulation, improve insulin sensitivity and have anti-inflammatory effects [65]. Higher intake of fruits and vegetables can reduce the energy density of the diet contributing to an important role in weigh management. Moreover, polyphenols and carotenoids contained in fruits and vegetables display beneficial effects on metabolic homeostasis and exert anti-inflammatory and anti-fibrotic effects, in NAFLD models, while suppressing activation of hepatic stellate cells [67]. High-fiber diets and whole grains have the potential to beneficially influence gut microbiota composition, which can be of relevance to the gut liver axis in the progression of NAFLD [68].

It should also be noted that a Mediterranean diet may be associated with a Mediterranean lifestyle, which may include adequate rest periods, differences in sun exposure and optimal physical activity, all of which may have a positive but independent impact on the course of NAFLD. Future well-designed studies exploring the longer term impact of the MD on the spectrum of NAFLD are required.

Table 1. Food group distribution in DASH and Mediterranean diets.

\begin{tabular}{|c|c|c|c|}
\hline \multicolumn{2}{|c|}{ DASH Diet } & \multicolumn{2}{|c|}{ Mediterranean Diet } \\
\hline Food Group & Daily Servings & Food Group & Daily Servings \\
\hline Whole grains & $7-8$ & \multirow{4}{*}{$\begin{array}{l}\text { Whole grains, vegetables, } \\
\text { fruits, seeds, olive oil, beans, } \\
\text { nuts, legumes }\end{array}$} & \multirow{4}{*}{$\begin{array}{l}\text { Base every meal on } \\
\text { these foods }\end{array}$} \\
\hline Vegetables & $4-5$ & & \\
\hline Fruits & $4-5$ & & \\
\hline Dairy, low-fat or non-fat & $2-3$ & & \\
\hline Lean meats, poultry, fish & 2 or fewer & Fish, seafood & Eat at least twice a week \\
\hline Nuts, seeds, dry beans & $4-5$ per week & Poultry, eggs, yogurt, cheese & $\begin{array}{l}\text { Eat moderate portions } \\
\text { daily to weekly }\end{array}$ \\
\hline Eats and oile & $2-3$ & Red meats & $<2$ servings/week \\
\hline Fats and olls & $2-3$ & Processed Meats & $<2$ servings/week \\
\hline Sweets & 5 per week & Sweets & $<1$ serving/week \\
\hline
\end{tabular}

\subsection{DASH Diet}

A “Dietary Approach to Stop Hypertension" (DASH) diet is a dietary pattern rich in vegetables, fruits, whole grains, low-fat dairy products, fish, poultry, nuts and legumes but with emphasis on low intake of sodium, total fat, saturated fat, cholesterol and added sugars (Table 1). The DASH diet is high in fiber, potassium, calcium and magnesium [69]. Although this dietary pattern was primarily designed for lowering blood pressure [69], by directly playing a beneficial role in insulin resistance and dyslipidemia [70] it has recently shown beneficial effects on other metabolic disorders including T2D [71], cardiovascular disease [72], and NAFLD [73,74]. A recent case-control study in 102 patients with newly diagnosed NAFLD and 204 matched controls evaluated the association between adherence to the DASH diet and the risk of NAFLD using a validated food frequency questionnaire. Although there was an inverse association between the DASH-style diet and risk of NAFLD, after adjusting for BMI and dyslipidemia the significance of this relationship disappeared [73]. In a recent eight-week RCT conducted in overweight and obese patients with NAFLD, the DASH diet resulted in a significant reduction in body weight, serum TG level, VLDL-cholesterol and liver enzymes, and concurrent improvement in insulin sensitivity, biomarkers of oxidative stress and inflammation (high sensitivity-CRP, nitric oxide (NO), glutathione (GSH) malondialdehyde) in the intervention group compared to controls [74]. 
Possible mechanisms for the protective role of the DASH diet include: (i) High fruit and vegetable consumption, resulting in higher intake of antioxidants [75], which may suppress the inflammatory processes in NAFLD; (ii) Higher intake of whole grains, which are associated with a lower risk of comorbidities linked to NAFLD [76]; (iii) Increased intake of nuts, which are rich in MUFAs, PUFAs and vitamin E, which may improve the serum lipid profile, reduce blood pressure, and have a favorable impact on oxidative stress [77]; (iv) Lower dietary intake of simple sugar. High sugar intake is associated with dyslipidemia, insulin resistance and central obesity [78]; (v) Higher intake of calcium and magnesium content of the DASH diet may have beneficial effects on insulin sensitivity and the anti-inflammatory response by decreasing oxidative activity and restoring anti-oxidative enzymes [79-81]. More studies are required in this field to determine the features of the DASH diet that are associated with the most benefit in patients with NAFLD.

\subsection{Fiber Intervention (Soluble, Prebiotic)}

Prebiotics are known as selectively fermented ingredients modulating changes in the composition and activities of the gut microbiome [82]. Prebiotics are often considered to be a subset of dietary fiber; however, not all dietary fiber has prebiotic qualities [36]. Prebiotic fiber is naturally found in foods such as garlic, asparagus, leek, chicory root and onions [26]. Benefits of prebiotics include: (i) stimulating bacterial production of short chain fatty acids; (ii) a selective modification of gut microbiota composition, reduction of the luminal $\mathrm{pH}$, inhibition of pathogen growth; (iii) improvement in glucose and lipid metabolisms [26]. We lack well-designed studies to evaluate the effects of prebiotic fiber on NAFLD. A review article reported that in patients with T2D and hyperlipidemia who consumed either inulin or fructooligosaccharide (FOS) supplements (prebiotic fiber), improvements in the TG (6-20\% reduction), cholesterol (14-27\% reduction) levels, or both were noted [83]. Oligofructose supplementation for three months significantly reduced body weight in overweight and obese adults, decreased self-reported calorie intake and improved glycemia [84]. Only one pilot study has assessed the effect of prebiotic fiber in NAFLD. In this study, seven NASH patients received $16 \mathrm{~g} /$ day of oligofructose in a randomized, double-blinded, crossover study. The results showed a significant decrease in serum ALT and aspartate aminotransferase (AST) levels, and an improvement in insulin level after four weeks [85].

\subsection{Omega-3 Interventions}

Several clinical studies have evaluated the impact of algal or marine omega-3 PUFAs on hepatic endpoints in NAFLD [47]. A recent study documented that marine omega-3 PUFA modulate hepatic lipid composition and TAG metabolism, and elevate mediators with anti-inflammatory features. All these modulations are beneficial in NAFLD treatment $[86,87]$. One of the first studies investigating the impact of omega-3 PUFA dates back to 2006 [88]. In this study, Cappani et al. demonstrated that fish oil ( $1 \mathrm{~g} /$ day for 12 months) as compared to control, resulted in a $60 \%$ improvement in risk factors such as a significantly decreasing the serum AST), ALT, $\gamma$-glutamyl transpeptidase (GGT), improving liver steatosis and reducing the $n-6 / n-3$ ratio $(p=0.0001)$ [88]. Since that time, a series of clinical trials and pilot studies have also supported the beneficial effects of omega-3 PUFAs with results on liver enzymes and hepatic steatosis. In 2008, two studies investigated the effect of calorie restricted diets with and without fish oil consumption $[89,90]$. Findings showed that fish oil in addition to calorie restriction was more protective than calorie restriction alone for the treatment of NAFLD. In another study, omega-3 PUFAs ( $2.7 \mathrm{~g} /$ day for 12 months) reduced plasma TAG level by $4.3 \%$ compared with baseline data, but had no effect on hepatic steatosis, inflammation, ballooning, or fibrosis score, and showed no improvement in liver enzymes levels, insulin resistance or proinflammatory markers [91]. Recently, two RCTs [92,93] used flaxseed oil as a source of omega-3 PUFAs in patients with NAFLD. One study showed a significantly greater reduction in liver enzymes, hepatic steatosis and fibrosis scores in flaxseed plus lifestyle modification compared to lifestyle modification alone [93]. In another study, Noguiera et al. used a mix of flaxseed oil and fish oil (0.945 $\mathrm{g} n-3 /$ day) and compared the results 
with mineral oil ( $2 \mathrm{~mL} /$ day). No histological improvement was found after a six-month intervention, except an improvement in lobular inflammation in the group receiving mineral oil [92]. Among all published reports using omega-3 PUFAs for NAFLD treatment, only five studies suggested that omega-3 PUFAs improved NAFLD independent of weight loss. Taken together, the data are discordant and larger well-designed clinical trials for longer periods are still needed to fully evaluate the beneficial effects of omega-3 PUFAs in NAFLD.

\subsection{Low-Fat vs. Low-CHO Interventions}

Low-CHO diets have become a common strategy for weight management across a variety of conditions. Although, a few studies have demonstrated that low $\mathrm{CHO}$ diets provide initial benefits on insulin resistance and liver fat, these results have not been sustainable in the long-term [94,95]. In 2011, Haufe et al. [96] performed a six-month trial comparing the effects of reduced fat and reduced $\mathrm{CHO}$ hypocaloric diets on intrahepatic fat assessed by magnetic resonance tomography in overweight and obese individuals. The results showed that a prolonged intervention with either low-CHO or low-fat diets had same effect on intrahepatic lipid accumulation, independent of visceral fat loss and changes in insulin sensitivity [96]. Another three-month intervention study was conducted in obese subjects with two intervention groups-one group received a calorie-restricted diet (1100 kcal/day) with low-CHO content $(<50 \mathrm{~g} /$ day) and the second group followed an isocaloric high-CHO diet $(>180 \mathrm{~g} /$ day). The result after $48 \mathrm{~h}$ showed an almost $30 \%$ reduction in intrahepatic TG in patients on the low-CHO diet and only a 10\% decrease on the high-CHO diet. The decrease of intrahepatic TG at the end of the study was similar in the two groups (40-50\% reduction) [95]. In five biopsy-proven NAFLD patients, a six-month low-CHO ketogenic diet (CHO less than $20 \mathrm{~g}$ per day) resulted in a significant improvement in steatosis and inflammatory response $(p=0.02)$ with a trend toward improvement in fibrosis [97]. Although interesting, these results are inconclusive given the absence of a comparative arm and the possibility that improvement may have been due to weight loss alone and not the particular diet. In another study, De Luis et al. [98] explored the effects of either a low-CHO or low-fat hypocaloric diet in NAFLD and obese patients for three months. In the NAFLD group, the low-fat diet showed weight loss had an improvement in anthropometric measurements (BMI, weight, fat mass), cardiovascular risk factors (blood pressure, TG, LDL- and total cholesterol levels) and liver enzymes (ALT, AST, GGT). The low-CHO diet resulted in an improvement in same parameters without statistical changes in AST [98]. A recent meta-analysis study supports that both low $/$ moderate fat $(\leq 30 \%$ of daily calorie intake) and moderate $\mathrm{CHO}(\leq 45 \%$ of daily calorie intake) diets have a similar beneficial effect on liver function by reducing ALT and AST levels [99].

Thus far, the limited available evidence supports the absence of a difference between low-CHO and low-fat diets as long as they are both calorie-restricted diets [96]. Long-term, interventional studies comparing these two diets, low-CHO and low-fat diets, are needed with an assessment of hepatic outcomes in patients with NAFLD.

\subsection{Probiotics}

Altered gut microbiota is associated with obesity, a risk factor for NAFLD. In animal studies, probiotics have been shown to prevent liver fibrosis [100]. In humans, Wong et al. demonstrated that patients with biopsy proven NASH treated with probiotics (Lactobacilli strains plus Bifidobacterium bifidum) compared with usual care had significantly lower intrahepatic triglyceride content measured by proton-magnetic resonance spectroscopy, independent of effect on BMI, waist circumference glucose or lipid levels [101]. Aller and colleagues investigated the impact of probiotic supplementation in 28 adults with NAFLD over three months. The probiotic intervention was comprised of 500 million colonies of Lactobacillus bulgaricus and Streptococcus thermophiles. Therapy was associated with a significant reduction in liver enzymes (ALT, AST and GGT; $p<0.05$ ) compared to the placebo group. No significant changes were found in anthropometrics and cardiovascular risk factors between groups [102]. Only one study evaluated an intervention using a probiotic food in NAFLD [103]. 
This randomized, double-blind, placebo-controlled clinical trial showed that consuming a probiotic yogurt with L. acidophilus La5 and B. lactis Bb12 for eight weeks in NAFLD patients reduced hepatic aminotransferases, and total and LDL cholesterol compared to patients consuming conventional yogurt [103]. In summary, the limited available data support the benefit of some probiotics, presumably related to modulation of liver function and reduction in dysbiosis, hepatic fat and TNF- $\alpha$ production. The translation of these findings to clinical practice is limited by the small number of studies and the variations in the probiotic strains, doses, and duration of the intervention period chosen across studies.

\section{Our Recommendations}

Weight loss achieved through lifestyle modification is the mainstay of therapy for NAFLD. Unfortunately, the sustainability of weight loss is poor and recidivism is frequently encountered, resulting in inadequate disease control. In this review we aimed to highlight the potential therapeutic role of a "high quality healthy diet" to improve liver steatosis and metabolic dysfunctions in patients with NAFLD above and beyond the known benefit of caloric restriction and weight loss. Our suggested dietary recommendations to manage NAFLD using dietary interventions include a eucaloric diet that is focused in the following principles:

(a) Moderate to high CHO intake: The recommended $\mathrm{CHO}$ intake is $45-65 \%$ of total daily calories, with a low preference for simple and unrefined sugar such as fructose-containing beverages and food; High preference for whole grains and low glycemic index foods. This improves hepatic fat accumulation and decreases hepatic fat accumulation.

(b) Low to moderate fat intake: The recommended fat intake is below $30-35 \%$ of total calories with a low preference for saturated and trans fat intake; High preference for healthy fat intake (MUFA and omega-3 PUFAs) found for example in olives, olive oil, seeds, nuts and fatty fish. This promotes glycemic control and may reduce inflammatory responses.

(c) Protein intake: The recommended protein intake is $15-20 \%$ of total daily calories, with minimization of red meat intake particularly processed meat, and increased consumption of poultry, fish, low- or non-fat dairy products and a blend of vegetable protein sources (beans and legumes). This improves cardiovascular risk factors and insulin sensitivity and decreases the risk of morbidity and mortality.

(d) Fiber and antioxidant intake: Increased consumption of fruits and vegetables, with more focus on prebiotic fiber. This provides beneficial effects on hepatic metabolism, which may be mediated through gut microbiome changes and reduction in calorie intake.

(e) Consider daily intake of probiotic enriched yogurt, containing L. acidophilus.

At this time, we do not have a definitive answer for the optimal proportions of total macronutrients ( $\mathrm{CHO}$, fat and protein) in the diet of NAFLD patients. A dietary composition based on the above recommendations may be of benefit in NAFLD, and overlaps with the Mediterranean Diet, which the EASL-EASD-EASO Clinical Guidelines have also recommended as the diet of choice for NAFLD treatment. Future studies evaluating the therapeutic effects of sustainable isocaloric dietary compositional changes will further increase our knowledge in this area.

Author Contributions: Raman developed the manuscript content, drafted the manuscript and approved the final version. Tandon developed the manuscript content, critically appraised the manuscript and approved the final version. Eslamparast contributed to developing the manuscript content, drafted the manuscript and approved the final version.

Conflicts of Interest: There are no conflicts of interest. 


\section{Appendix A}

Table A1. Published clinical trials on the effect of dietary compositions and patterns in adult patients with NAFLD.

\begin{tabular}{|c|c|c|c|c|c|c|c|}
\hline \multicolumn{8}{|c|}{ Mediterranean Diet } \\
\hline Author/Year & $\begin{array}{l}\text { Method of } \\
\text { Diagnosis }\end{array}$ & Study Design, No. of Cases & Intervention & $\begin{array}{l}\text { Hepatic Fat Outcomes, } \\
\text { Imaging Modality }\end{array}$ & Results & $\begin{array}{l}\text { Compliance and } \\
\text { Adherence }\end{array}$ & $\begin{array}{c}\text { Drop-Out } \\
\text { Rates }\end{array}$ \\
\hline $\begin{array}{l}\text { Ryan et al. } \\
2013 \text { [64] }\end{array}$ & biopsy & $\begin{array}{l}\text { Randomized, cross-over trial; } \\
12 \text { obese, non-diabetic } \\
\text { NAFLD pts }\end{array}$ & $\begin{array}{l}6 \text { weeks, MD vs. standard low } \\
\text { fat/high CHO (LFHC) Diet }\end{array}$ & $1 \mathrm{H}-\mathrm{MRS}$ & $\begin{array}{l}39 \% \text { reduction in hepatic steatosis in MD group vs. } \\
7 \% \text { reduction in LFHC diet; A significant } \\
\text { improvement in insulin sensitivity (HOMA-IR and } \\
\text { circulating insulin level) and a significant reduction } \\
\text { in systolic blood pressure only in MD group } \\
\text { independent of weight loss; No difference in serum } \\
\text { ALT and GGT; No difference in body weight. }\end{array}$ & Not reported & None \\
\hline $\begin{array}{l}\text { Trovato et al. } \\
2015 \text { [104] }\end{array}$ & US & $\begin{array}{l}\text { Single arm trial; } \\
90 \text { overweight, non-diabetic } \\
\text { NAFLD pts }\end{array}$ & 6 months, MD & US & $\begin{array}{l}\text { A significant decrease in liver steatosis and } \\
\text { HOMA-IR; No significant change in ALT } \\
\text { (baseline values were in normal range); the effect of } \\
\text { adherence to MD was significantly observed at the } \\
\text { sixth month; BMI significantly reduced }\end{array}$ & Not reported & None \\
\hline $\begin{array}{l}\text { Abenavoli et al. } \\
2015 \text { [105] }\end{array}$ & US & $\begin{array}{l}\text { Randomized controlled trial; } \\
30 \text { overweight NAFLD pts }\end{array}$ & $\begin{array}{l}6 \text { months, Group A: } \\
\text { a personalized MD } \\
\text { Group B: a personalized MD + } \\
\text { Realsil complex * daily } \\
\text { Group C: No treatment }\end{array}$ & NE & $\begin{array}{l}\text { MD alone or in association with Realsil complex } \\
\text { showed a significant improvement in BMI, waist } \\
\text { circumferences, total cholesterol and TG; } \\
\text { A significant reduction in HOMO-IR in group B pts; } \\
\text { Significant decrease in weight. }\end{array}$ & Not reported & None \\
\hline \multicolumn{8}{|l|}{ DASH Diet } \\
\hline $\begin{array}{l}\text { Razavi Zade et al. } \\
2016 \text { [74] }\end{array}$ & US & $\begin{array}{l}\text { Randomized controlled trial; } \\
60 \text { overweight and obese } \\
\text { NAFLD pts }\end{array}$ & $\begin{array}{l}8 \text { weeks, calorie-restricted DASH diet } \\
\text { vs. control calorie-restricted diet } \\
\text { Calorie restricted diet: } 52-55 \% \mathrm{CHO} \text {, } \\
16-18 \% \text { protein and } 30 \% \text { fat }\end{array}$ & $\mathrm{NE}$ & $\begin{array}{l}\text { A significant reduction in weight, BMI, ALT, AST, } \\
\text { and improvement in insulin sensitivity in DASH } \\
\text { diet group compared to control group; Significant } \\
\text { reduction in inflammatory response (hs-CRP and } \\
\text { MDA), an increase in antioxidant profiles (NO and } \\
\text { GSH) in DASH group compared to control. }\end{array}$ & Not reported & 6 out of 60 \\
\hline \multicolumn{8}{|c|}{ Fiber Intervention (Soluble, Prebiotic) } \\
\hline $\begin{array}{l}\text { Daubioul et al. } \\
2005 \text { [85] }\end{array}$ & biopsy & $\begin{array}{l}\text { Randomized, double blind } \\
\text { cross-over trial; } 7 \text { NASH pts }\end{array}$ & $\begin{array}{l}8 \text { weeks, } 16 \mathrm{~g} / \text { day oligofructose } \\
\text { (OFS) vs. placebo (maltodextrin) }\end{array}$ & US & $\begin{array}{l}\text { A significant decrease in serum ALT, AST and } \\
\text { insulin level in OFS group; No significant changes } \\
\text { in liver size and liver fatty infiltration; Effects on } \\
\text { body weight not reported }\end{array}$ & Not reported & Not reported \\
\hline \multicolumn{8}{|c|}{ Omega-3 Interventions } \\
\hline $\begin{array}{l}\text { Hatziolios et al. } \\
2004 \text { [106] }\end{array}$ & US & $\begin{array}{l}\text { Clinical trial; } 72 \text { NAFLD pts } \\
\text { with dyslipidemia }\end{array}$ & $\begin{array}{l}24 \text { weeks, Group A: } 15 \mathrm{~mL} / \text { day Fish } \\
\text { oil (EPA 2.25 g/day + DHA 1.58) } \\
\text { Group B: orlistat intervention } \\
\text { Group C: atorvastatin intervention }\end{array}$ & US, biopsy & $\begin{array}{l}35 \% \text { improvement in resolution of hepatic steatosis } \\
\text { in group A, } 61 \% \text { in group B, and } 86 \% \text { in group C; } \\
\text { A significant reduction in liver transaminases in all } \\
\text { groups; No significant change in BMI }\end{array}$ & Not reported & 1 out of 73 \\
\hline $\begin{array}{l}\text { Capanni et al. } \\
2006[88]\end{array}$ & US & Pilot trial; 56 NAFLD pts & $\begin{array}{l}12 \text { months, } 1 \mathrm{~g} / \text { day } n-3 \text { PUFAs } \\
\text { (EPA and DHA in the ratio of } 0.9 / 1.5 \\
\text { respectively) }\end{array}$ & US & $\begin{array}{l}\text { Serum ALT, AST, GGT, TG and fasting glucose } \\
\text { significantly decreased in intervention group; } \\
\text { A significant reduction in } n-6 / n-3 \text { PUFA ratio and } \\
\text { improvement in hepatic steatosis in treated group; } \\
\text { No change in BMI. }\end{array}$ & Not reported & None \\
\hline
\end{tabular}


Table A1. Cont.

\begin{tabular}{|c|c|c|c|c|c|c|c|}
\hline \multicolumn{8}{|l|}{ Mediterranean Diet } \\
\hline Author/Year & $\begin{array}{l}\text { Method of } \\
\text { Diagnosis }\end{array}$ & Study Design, No. of Cases & Intervention & $\begin{array}{l}\text { Hepatic Fat Outcomes, } \\
\text { Imaging Modality }\end{array}$ & Results & $\begin{array}{l}\text { Compliance and } \\
\text { Adherence }\end{array}$ & $\begin{array}{l}\text { Drop-Out } \\
\text { Rates }\end{array}$ \\
\hline $\begin{array}{l}\text { Tanaka et al. } \\
2008 \text { [107] }\end{array}$ & biopsy & $\begin{array}{l}\text { Single arm pilot trial; } \\
23 \text { NASH pts }\end{array}$ & 6 months, $2.7 \mathrm{~g} /$ day EPA & biopsy (only in 7 pts) & $\begin{array}{l}\text { A significant improvement serum ALT, FFAs; } \\
\text { a significant reduction in hepatic oxidative stress } \\
\text { factors; An improvement in liver histology in } 6 \text { pts; } \\
\text { No change in weight, glucose, insulin and } \\
\text { adiponectin levels; No significant difference } \\
\text { in body weight. }\end{array}$ & Not reported & None \\
\hline $\begin{array}{l}\text { Vega et al. } \\
2008[108]\end{array}$ & MRS & Sequential design; & $\begin{array}{l}4 \text { weeks of placebo followed by } \\
8 \text { weeks treatment with } 9 \mathrm{~g} / \text { day } \\
\text { fish oils }\end{array}$ & MRS & $\begin{array}{l}46 \% \text { reduction in plasma TG, } 21 \% \text { reduction in LDL } \\
\text { and IDL and } 15 \% \text { reduction in total apo-B; No } \\
\text { significant changes in intrahepatic TG by fish oil } \\
\text { treatment; No significant change in body weight }\end{array}$ & Not reported & 5 out of 22 \\
\hline Zhu et al. 2008 [90] & US & $\begin{array}{l}\text { Randomized, controlled trial; } \\
\text { 134 NAFLD pts with } \\
\text { hyperlipidemia }\end{array}$ & $\begin{array}{l}24 \text { weeks, } 6 \mathrm{~g} / \text { day } n-3 \text { PUFA from } \\
\text { seal oils vs. placebo group; } \\
\text { both group received } \\
\text { AHA-recommended diet } \\
\text { AHA-recommended diet: } 50 \% \mathrm{CHO} \text {, } \\
20 \% \text { protein and } 30 \% \text { fat, hypocaloric } \\
\text { diet (25-30 kcal } / \mathrm{kg} \text { BW) was advised } \\
\text { to overweight pts }\end{array}$ & US & $\begin{array}{l}\text { A significant reduction in ALT, TG and } \\
\text { LDL-cholesterol in PUFA group and a tendency } \\
\text { toward improvement in GGT, AST, HDL- and total } \\
\text { cholesterol in the both groups; A normalization in } \\
\text { ultrasonographic evidence; No significant changes } \\
\text { in BW and fasting glucose }\end{array}$ & Not reported & 10 out of 134 \\
\hline $\begin{array}{l}\text { Spadaro et al. } \\
2008 \text { [89] }\end{array}$ & US & $\begin{array}{l}\text { Randomized, controlled trial; } \\
40 \text { pts with hyperlipidemia }\end{array}$ & $\begin{array}{l}6 \text { months, } 2 \mathrm{~g} / \text { day } n-3 \text { PUFAs + } \\
\text { AHA-recommended diet vs. } \\
\text { AHA-recommended diet alone }\end{array}$ & US & $\begin{array}{l}\text { An improvement in ALT, TG and TNF- } \alpha \text { in PUFA } \\
\text { group; A normalization in ultrasonographic features } \\
\text { of NAFLD; BMI levels were decreased in } \\
\text { both groups. }\end{array}$ & Not reported & 4 out of 40 \\
\hline $\begin{array}{l}\text { Scorletti et al. } \\
2014 \text { [109] } \\
\text { WELCOME study }\end{array}$ & $\begin{array}{l}\text { Radiological- } \\
\text { or } \\
\text { biopsy-proven }\end{array}$ & $\begin{array}{l}\text { Randomized double blind } \\
\text { placebo controlled trial; } \\
95 \text { NAFLD pts }\end{array}$ & $\begin{array}{l}18 \text { months, } 4 \mathrm{~g} / \text { day } n-3 \text { PUFA } \\
\text { (DHA + EPA) vs. placebo ( } 4 \mathrm{~g} / \text { day } \\
\text { olive oil) }\end{array}$ & MRS & $\begin{array}{l}\text { A marginal reduction in intrahepatic TG in PUFA } \\
\text { group; Change in body weight not reported. }\end{array}$ & Not reported & 8 out of 103 \\
\hline $\begin{array}{l}\text { Sanyal et al. } \\
2014 \text { [91] }\end{array}$ & $\begin{array}{l}\text { biopsy } \\
(\text { NAS }>40)\end{array}$ & $\begin{array}{l}\text { Randomized, controlled trial; } \\
234 \text { NAFH pts }\end{array}$ & $\begin{array}{l}12 \text { months, } 1.8 \mathrm{~g} / \text { day EPA-E } \\
\text { (low-dose) vs. } 2.7 \mathrm{~g} / \text { day EPA-E } \\
\text { (high-dose) vs. placebo }\end{array}$ & biopsy & $\begin{array}{l}35-40 \% \text { reduction in NAS, no fibrosis worsening, } \\
\text { without any difference between groups; } \\
\text { A significant reduction in TG levels, but no effects of } \\
\text { EAA-E on biochemical and histological features; } \\
\text { No significant change in body weight }\end{array}$ & $\begin{array}{l}\text { Overall } \\
\text { compliance rate } \\
\text { around } 90 \%\end{array}$ & 15 out of 243 \\
\hline $\begin{array}{l}\text { Argo et al. } \\
2015 \text { [102] }\end{array}$ & biopsy & $\begin{array}{l}\text { Randomized, controlled trial; } \\
34 \text { non-cirrhotic NASH pts }\end{array}$ & $\begin{array}{l}12 \text { months, } 3 \mathrm{~g} / \text { day } n-3 \text { PUFAs vs. } \\
\text { placebo }\end{array}$ & biopsy, MRI & $\begin{array}{l}\text { N-3 PUFAs group showed a greater reduction in } \\
\text { intrahepatic TG in individuals with increased or } \\
\text { stable BW; No improvement in NAS score } \\
\text { ( } \geq 2 \text { without fibrosis progression); No effect on } \\
\text { hepatocellulari injury and IR; No significant change } \\
\text { in body weight. }\end{array}$ & Not reported & 7 out of 41 \\
\hline $\begin{array}{l}\text { Dasarathy et al. } \\
2015 \text { [110] }\end{array}$ & biopsy & $\begin{array}{l}\text { Randomized, double blinded, } \\
\text { placebo-controlled trial; } \\
37 \text { well-controlled diabetic } \\
\text { NASH pts }\end{array}$ & $\begin{array}{l}48 \text { weeks, } 2.16 \mathrm{~g} / \text { day EPA }+ \\
1.44 \mathrm{~g} / \text { day DHA vs. placebo } \\
\text { (corn oil) }\end{array}$ & biopsy & $\begin{array}{l}\text { No change in liver enzymes, BW and body } \\
\text { composition; In placebo group, hepatic steatosis and } \\
\text { NAS score improved and lobular inflammation } \\
\text { worsened but no changes in PUFA group; } \\
\text { An increase in HOMA-IR in PUFA group }\end{array}$ & Not reported & None \\
\hline
\end{tabular}


Table A1. Cont.

\begin{tabular}{|c|c|c|c|c|c|c|c|}
\hline \multicolumn{8}{|l|}{ Mediterranean Diet } \\
\hline Author/Year & $\begin{array}{l}\text { Method of } \\
\text { Diagnosis }\end{array}$ & Study Design, No. of Cases & Intervention & $\begin{array}{l}\text { Hepatic Fat Outcomes, } \\
\text { Imaging Modality }\end{array}$ & Results & $\begin{array}{l}\text { Compliance and } \\
\text { Adherence }\end{array}$ & $\begin{array}{c}\text { Drop-Out } \\
\text { Rates }\end{array}$ \\
\hline Li et al. 2015 [111] & biopsy & $\begin{array}{l}\text { Prospective, randomized, } \\
\text { controlled, unblended trial; } 78 \\
\text { NASH pts }\end{array}$ & $\begin{array}{l}6 \text { months, } 50 \mathrm{~mL} / \text { day } n-3 \text { PUFA } \\
\text { (1:1 ratio EPA:DHA) vs. placebo } \\
\text { (prescribed normal saline) } \\
\text { Recommended diet for both group: } \\
\text { low-fat/low-CHO diet }+30 \mathrm{~min} \\
\text { modest physical exercise at least } \\
5 \text { days/week }\end{array}$ & biopsy & $\begin{array}{l}\text { A significant reduction in liver function (ALT, AST), } \\
\text { serum TG, total cholesterol and metabolic profiles in } \\
\text { PUSA group; A reduction in BMI in both groups; } \\
\text { A significant improvement in severity of NASH in } \\
\text { treated group }\end{array}$ & Not reported & None \\
\hline $\begin{array}{l}\text { Nogueira et al. } \\
2016[92]\end{array}$ & biopsy & $\begin{array}{l}\text { Randomized, double blinded, } \\
\text { controlled trial; } 50 \text { NASH pts }\end{array}$ & $\begin{array}{l}6 \text { months, } 0.945 \mathrm{~g} / \text { day } n-3 \text { PUFA } \\
(64 \% \text { ALA }+16 \% \text { EPA + } 21 \% \text { DHA) } \\
\text { vs. placebo (mineral oil) }\end{array}$ & biopsy & $\begin{array}{l}\text { A significant increase in plasma } n-3 \text { PUFA in both } \\
\text { group; NAS score improvement/stabilization was } \\
\text { significantly correlated with increased plasma } n-3 \\
\text { PUFAs in both group; A significant reduction in TG } \\
\text { level in PUFA group; BMI did not change } \\
\text { significantly }\end{array}$ & Not reported & 10 out of 60 \\
\hline \multicolumn{8}{|c|}{ Low-Fat Diet vs. Low-CHO Diet } \\
\hline $\begin{array}{l}\text { Petersen et al. } \\
2005[112]\end{array}$ & 1H-MRS & $\begin{array}{l}\text { Clinical trial; } 8 \text { obese, diabetic } \\
\text { pts with non-alcoholic } \\
\text { steatosis }\end{array}$ & $\begin{array}{l}12 \text { weeks moderately hypocaloric } \\
\text { very-low-fat }(3 \%) \text { followed by } \\
4 \text { weeks of isocaloric diet } \\
\text { Group 1: patients }(n=8) \\
\text { Group 2: healthy controls }(n=10)\end{array}$ & 1H-MRS & $\begin{array}{l}\text { A } 8 \mathrm{~kg} \text { weight loss significantly improved glucose } \\
\text { metabolism; A } 81 \% \text { reduction in intrahepatic TG }\end{array}$ & Not reported & None \\
\hline $\begin{array}{l}\text { Tendler et al. } \\
2007 \text { [97] }\end{array}$ & biopsy & $\begin{array}{l}\text { Single arm pilot study; } 5 \\
\text { obese NAFLD pts }\end{array}$ & $\begin{array}{l}3 \text { months, low-CHO ketogenic diet } \\
\text { ( }<20 \mathrm{~g} / \text { day CHO) with nutritional } \\
\text { supplementation (free of any weight } \\
\text { loss-induced formula) } \\
\text { No restriction on the amount of } \\
\text { calorie intake }\end{array}$ & biopsy & $\begin{array}{l}\text { A } 12.8 \mathrm{~kg} \text { weight loss after treatment; A significant } \\
\text { improvement in liver histology in } 4 \text { pts }\end{array}$ & Not reported & None \\
\hline $\begin{array}{l}\text { Kirk et al. } \\
2009 \text { [95] }\end{array}$ & 1H-MRS & $\begin{array}{l}\text { Randomized clinical trial; } 22 \\
\text { obese pts (NAFLD pts: } 50 \% \text { of } \\
\text { pts in high CHO diet, } 58 \% \text { of } \\
\text { pts in low CHO diet) }\end{array}$ & $\begin{array}{l}11 \text { weeks, Group 1: high CHO diet } \\
\text { ( } 180 \mathrm{~g} / \text { day }) \\
\text { Group 2: low CHO diet ( }<50 \mathrm{~g} / \text { day) }\end{array}$ & 1H-MRS & $\begin{array}{l}\text { After } 48 \mathrm{~h} \text {, an almost } 30 \% \text { reduction in intrahepatic } \\
\text { TG on low-CHO diet and only } 10 \% \text { decrease on } \\
\text { high-CHO diet; A decrease of intrahepatic TG at the } \\
\text { end of the study in both groups ( } 40-50 \% \text { reduction); } \\
7 \% \text { weight loss in both groups }\end{array}$ & $\begin{array}{l}\text { Subjects in both } \\
\text { groups were } \\
\text { compliant with the } \\
\text { diet }\end{array}$ & None \\
\hline $\begin{array}{l}\text { De Luis et al. } \\
2010[98]\end{array}$ & $\begin{array}{l}\text { Elevated } \\
\text { liver enzyme } \\
\text { (ALT) }\end{array}$ & $\begin{array}{l}\text { Randomized clinical trial; } 28 \\
\text { obese NAFLD pts }\end{array}$ & $\begin{array}{l}3 \text { months, Group 1: Pts with normal } \\
\text { ALT activity (control; } n=134) \\
\text { Group 2: NAFLD pts }(n=28) \\
\text { Diet I: low fat } \\
\text { Diet II: low CHO }\end{array}$ & $\mathrm{NE}$ & $\begin{array}{l}\text { In NAFLD group, low-fat diet showed weight loss } \\
\text { and an improvement in anthropometric } \\
\text { measurements, cardiovascular risk factors and liver } \\
\text { enzymes; and low-CHO diet resulted in an } \\
\text { improvement in same parameters without statistical } \\
\text { changes in AST }\end{array}$ & Not reported & None \\
\hline $\begin{array}{l}\text { Abbreviations } \\
\text { Model Assessn } \\
\text { C-reactive pro } \\
\text { weight; AHA, } \\
\text { IDL, intermedi }\end{array}$ & $\begin{array}{l}\text { s: NAFLD, no } \\
\text { nent of Insuli } \\
\text { tein; MDA, m } \\
\text { American H } \\
\text { iate density li }\end{array}$ & $\begin{array}{l}\text { Resistance; ALT, alanin } \\
\text { londialdehyde; NO, nit } \\
\text { art Association; TNF, tu } \\
\text { oprotein; apo-B, apolip }\end{array}$ & $\begin{array}{l}\text { e; pts patient; MD, Mediterrar } \\
\text { inotransferase; NE, not evalua } \\
\text { xide; GSH, glutathione; NASH } \\
\text { r necrosis factor; NAS, NAFL } \\
\text { tein B; BMI, body mass index; }\end{array}$ & I diet; H-MRS, H-M & $\begin{array}{l}\text { etic Resonance Spectroscopy; US, Ultrasou } \\
\text {, carbohydrate, GGT, } \gamma \text {-glutamyl transpeptic } \\
\text { titis; EPA, eicosapentaenoic acid; DHA, doc } \\
\text { netic resonance imaging; IR, insulin resista } \\
\text { ferase. * Realsil complex: a complex of silyb }\end{array}$ & $\begin{array}{l}\text { d; HOMA-IR, H } \\
\text { se; hs-CRP, high } \\
\text { sahexaenoic acid } \\
\text { hce; ALA, } \alpha \text {-Linc } \\
\text { n, phosphatidylc }\end{array}$ & $\begin{array}{l}\text { meostatic } \\
\text { sensitivity } \\
\text { BW, body } \\
\text { lenic acid; } \\
\text { loline and }\end{array}$ \\
\hline
\end{tabular}




\section{References}

1. Fazel, Y.; Koenig, A.B.; Sayiner, M.; Goodman, Z.D.; Younossi, Z.M. Epidemiology and natural history of non-alcoholic fatty liver disease. Metabolism 2016, 65, 1017-1025. [CrossRef] [PubMed]

2. Younossi, Z.M.; Koenig, A.B.; Abdelatif, D.; Fazel, Y.; Henry, L.; Wymer, M. Global epidemiology of nonalcoholic fatty liver disease-Meta-analytic assessment of prevalence, incidence, and outcomes. Hepatology 2016, 64, 73-84. [CrossRef] [PubMed]

3. Abenavoli, L.; Milic, N.; Di Renzo, L.; Preveden, T.; Medic-Stojanoska, M.; De Lorenzo, A. Metabolic aspects of adult patients with nonalcoholic fatty liver disease. World J. Gastroenterol. 2016, 22, 7006-7016. [CrossRef] [PubMed]

4. Angulo, P. Nonalcoholic fatty liver disease. N. Engl. J. Med. 2002, 346, 1221-1231. [CrossRef] [PubMed]

5. Loomba, R.; Sanyal, A.J. The global NAFLD epidemic. Nat. Rev. Gastroenterol. Hepatol. 2013, 10, 686-690. [CrossRef] [PubMed]

6. Yatsuji, S.; Hashimoto, E.; Tobari, M.; Taniai, M.; Tokushige, K.; Shiratori, K. Clinical features and outcomes of cirrhosis due to non-alcoholic steatohepatitis compared with cirrhosis caused by chronic hepatitis C. J. Gastroenterol. Hepatol. 2009, 24, 248-254. [CrossRef] [PubMed]

7. Guzman, G.; Brunt, E.M.; Petrovic, L.M.; Chejfec, G.; Layden, T.J.; Cotler, S.J. Does nonalcoholic fatty liver disease predispose patients to hepatocellular carcinoma in the absence of cirrhosis? Arch. Pathol. Lab. Med. 2008, 132, 1761-1766. [CrossRef] [PubMed]

8. Vizuete, J.; Camero, A.; Malakouti, M.; Garapati, K.; Gutierrez, J. Perspectives on Nonalcoholic Fatty Liver Disease: An Overview of Present and Future Therapies. J. Clin. Transl. Hepatol. 2017, 5, 67-75. [CrossRef] [PubMed]

9. Ouyang, X.; Cirillo, P.; Sautin, Y.; McCall, S.; Bruchette, J.L.; Diehl, A.M.; Johnson, R.J.; Abdelmalek, M.F. Fructose consumption as a risk factor for non-alcoholic fatty liver disease. J. Hepatol. 2008, 48, 993-999. [CrossRef] [PubMed]

10. Zelber-Sagi, S.; Nitzan-Kaluski, D.; Goldsmith, R.; Webb, M.; Blendis, L.; Halpern, Z.; Oren, R. Long term nutritional intake and the risk for non-alcoholic fatty liver disease (NAFLD): A population based study. J. Hepatol. 2007, 47, 711-717. [CrossRef] [PubMed]

11. Musso, G.; Gambino, R.; De Michieli, F.; Cassader, M.; Rizzetto, M.; Durazzo, M.; Faga, E.; Silli, B.; Pagano, G. Dietary habits and their relations to insulin resistance and postprandial lipemia in nonalcoholic steatohepatitis. Hepatology 2003, 37, 909-916. [CrossRef] [PubMed]

12. Yasutake, K.; Nakamuta, M.; Shima, Y.; Ohyama, A.; Masuda, K.; Haruta, N.; Fujino, T.; Aoyagi, Y.; Fukuizumi, K.; Yoshimoto, T.; et al. Nutritional investigation of non-obese patients with non-alcoholic fatty liver disease: The significance of dietary cholesterol. Scand. J. Gastroenterol. 2009, 44, 471-477. [CrossRef] [PubMed]

13. European Association for the Study of the Liver (EASL); European Association for the Study of Diabetes (EASD); European Association for the Study of Obesity (EASO). EASL-EASD-EASO Clinical Practice Guidelines for the management of non-alcoholic fatty liver disease. J. Hepatol. 2016, 64, 1388-1402. [CrossRef]

14. Fontana, L.; Meyer, T.E.; Klein, S.; Holloszy, J.O. Long-term calorie restriction is highly effective in reducing the risk for atherosclerosis in humans. Proc. Natl. Acad. Sci. USA. 2004, 101, 6659-6663. [CrossRef] [PubMed]

15. Ratziu, V. Non-pharmacological interventions in non-alcoholic fatty liver disease patients. Liver Int. 2017, 37 (Suppl. 1), 90-96. [CrossRef] [PubMed]

16. Ong, J.P.; Younossi, Z.M. Epidemiology and natural history of NAFLD and NASH. Clin. Liver Dis. 2007, 11, 1-16. [CrossRef] [PubMed]

17. Day, C.P. Pathogenesis of steatohepatitis. Best Pract. Res. Clin. Gastroenterol. 2002, 16, 663-678. [CrossRef] [PubMed]

18. Rolo, A.P.; Teodoro, J.S.; Palmeira, C.M. Role of oxidative stress in the pathogenesis of nonalcoholic steatohepatitis. Free Radic. Biol. Med. 2012, 52, 59-69. [CrossRef] [PubMed]

19. Takaki, A.; Kawai, D.; Yamamoto, K. Multiple hits, including oxidative stress, as pathogenesis and treatment target in non-alcoholic steatohepatitis (NASH). Int. J. Mol. Sci. 2013, 14, 20704-20728. [CrossRef] [PubMed]

20. Buzzetti, E.; Pinzani, M.; Tsochatzis, E.A. The multiple-hit pathogenesis of non-alcoholic fatty liver disease (NAFLD). Metabolism 2016, 65, 1038-1048. [CrossRef] [PubMed] 
21. Yang, L.; Li, P.; Fu, S.; Calay, E.S.; Hotamisligil, G.S. Defective hepatic autophagy in obesity promotes ER stress and causes insulin resistance. Cell Metab. 2010, 11, 467-478. [CrossRef] [PubMed]

22. Hardy, T.; Oakley, F.; Anstee, Q.M.; Day, C.P. Nonalcoholic Fatty Liver Disease: Pathogenesis and Disease Spectrum. Annu. Rev. Pathol. 2016, 11, 451-496. [CrossRef] [PubMed]

23. Malhi, H.; Gores, G.J.; Lemasters, J.J. Apoptosis and necrosis in the liver: A tale of two deaths? Hepatology 2006, 43, S31-S44. [CrossRef] [PubMed]

24. Chang, L.; Chiang, S.-H.; Saltiel, A.R. Insulin signaling and the regulation of glucose transport. Mol. Med. 2004, 10, 65-71. [CrossRef] [PubMed]

25. Martin-Dominguez, V.; Gonzalez-Casas, R.; Mendoza-Jimenez-Ridruejo, J.; Garcia-Buey, L.; Moreno-Otero, R. Pathogenesis, diagnosis and treatment of non-alcoholic fatty liver disease. Rev. Esp. Enferm. Dig. 2013, 105, 409-420. [CrossRef] [PubMed]

26. Parnell, J.A.; Raman, M.; Rioux, K.P.; Reimer, R.A. The potential role of prebiotic fibre for treatment and management of non-alcoholic fatty liver disease and associated obesity and insulin resistance. Liver Int. 2012, 32, 701-711. [CrossRef] [PubMed]

27. Ley, R.E.; Turnbaugh, P.J.; Klein, S.; Gordon, J.I. Microbial ecology: Human gut microbes associated with obesity. Nature 2006, 444, 1022-1023. [CrossRef] [PubMed]

28. Garner, C.E.; Smith, S.; de Lacy Costello, B.; White, P.; Spencer, R.; Probert, C.S.J.; Ratcliffe, N.M. Volatile organic compounds from feces and their potential for diagnosis of gastrointestinal disease. FASEB J. Off. Publ. Fed. Am. Soc. Exp. Biol. 2007, 21, 1675-1688. [CrossRef] [PubMed]

29. Raman, M.; Ahmed, I.; Gillevet, P.M.; Probert, C.S.; Ratcliffe, N.M.; Smith, S.; Greenwood, R.; Sikaroodi, M.; Lam, V.; Crotty, P.; et al. Fecal microbiome and volatile organic compound metabolome in obese humans with nonalcoholic fatty liver disease. Clin. Gastroenterol. Hepatol. 2013, 11, 863-868. [CrossRef] [PubMed]

30. Allard, J.P.; Aghdassi, E.; Mohammed, S.; Raman, M.; Avand, G.; Arendt, B.M.; Jalali, P.; Kandasamy, T.; Prayitno, N.; Sherman, M.; et al. Nutritional assessment and hepatic fatty acid composition in non-alcoholic fatty liver disease (NAFLD): A cross-sectional study. J. Hepatol. 2008, 48, 300-307. [CrossRef] [PubMed]

31. Eslamparast, T.; Eghtesad, S.; Hekmatdoost, A.; Poustchi, H. Probiotics and Nonalcoholic Fatty liver Disease. Middle East J. Dig. Dis. 2013, 5, 129-136. [PubMed]

32. Jirillo, E.; Caccavo, D.; Magrone, T.; Piccigallo, E.; Amati, L.; Lembo, A.; Kalis, C.; Gumenscheimer, M. The role of the liver in the response to LPS: Experimental and clinical findings. J. Endotoxin Res. 2002, 8, 319-327. [CrossRef] [PubMed]

33. Abu-Shanab, A.; Quigley, E.M.M. The role of the gut microbiota in nonalcoholic fatty liver disease. Nat. Rev. Gastroenterol. Hepatol. 2010, 7, 691-701. [CrossRef] [PubMed]

34. Nolan, J.P. Endotoxin, reticuloendothelial function, and liver injury. Hepatology 1981, 1, 458-465. [CrossRef] [PubMed]

35. Tilg, H.; Moschen, A.R. Evolution of inflammation in nonalcoholic fatty liver disease: The multiple parallel hits hypothesis. Hepatology 2010, 52, 1836-1846. [CrossRef] [PubMed]

36. Saez-Lara, M.J.; Robles-Sanchez, C.; Ruiz-Ojeda, F.J.; Plaza-Diaz, J.; Gil, A. Effects of Probiotics and Synbiotics on Obesity, Insulin Resistance Syndrome, Type 2 Diabetes and Non-Alcoholic Fatty Liver Disease: A Review of Human Clinical Trials. Int. J. Mol. Sci. 2016, 17, 928. [CrossRef] [PubMed]

37. Ilan, Y. Leaky gut and the liver: A role for bacterial translocation in nonalcoholic steatohepatitis. World J. Gastroenterol. 2012, 18, 2609-2618. [CrossRef] [PubMed]

38. Fain, J.N.; Bahouth, S.W.; Madan, A.K. TNFalpha release by the nonfat cells of human adipose tissue. Int. J. Obes. Relat. Metab. Disord. 2004, 28, 616-622. [CrossRef] [PubMed]

39. Wehmeyer, M.H.; Zyriax, B.-C.; Jagemann, B.; Roth, E.; Windler, E.; Schulze Zur Wiesch, J.; Lohse, A.W.; Kluwe, J. Nonalcoholic fatty liver disease is associated with excessive calorie intake rather than a distinctive dietary pattern. Medicine (Baltimore) 2016, 95, e3887. [CrossRef] [PubMed]

40. Cortez-Pinto, H.; Jesus, L.; Barros, H.; Lopes, C.; Moura, M.C.; Camilo, M.E. How different is the dietary pattern in non-alcoholic steatohepatitis patients? Clin. Nutr. 2006, 25, 816-823. [CrossRef] [PubMed]

41. Volynets, V.; Kuper, M.A.; Strahl, S.; Maier, I.B.; Spruss, A.; Wagnerberger, S.; Konigsrainer, A.; Bischoff, S.C.; Bergheim, I. Nutrition, intestinal permeability, and blood ethanol levels are altered in patients with nonalcoholic fatty liver disease (NAFLD). Dig. Dis. Sci. 2012, 57, 1932-1941. [CrossRef] [PubMed] 
42. Toshimitsu, K.; Matsuura, B.; Ohkubo, I.; Niiya, T.; Furukawa, S.; Hiasa, Y.; Kawamura, M.; Ebihara, K.; Onji, M. Dietary habits and nutrient intake in non-alcoholic steatohepatitis. Nutrition 2007, 23, 46-52. [CrossRef] [PubMed]

43. Jia, Q.; Xia, Y.; Zhang, Q.; Wu, H.; Du, H.; Liu, L.; Wang, C.; Shi, H.; Guo, X.; Liu, X.; et al. Dietary patterns are associated with prevalence of fatty liver disease in adults. Eur. J. Clin. Nutr. 2015, 69, 914-921. [CrossRef] [PubMed]

44. Tajima, R.; Kimura, T.; Enomoto, A.; Yanoshita, K.; Saito, A.; Kobayashi, S.; Masuda, K.; Iida, K. Association between rice, bread, and noodle intake and the prevalence of non-alcoholic fatty liver disease in Japanese middle-aged men and women. Clin. Nutr. 2016. [CrossRef] [PubMed]

45. Cheng, Y.; Zhang, K.; Chen, Y.; Li, Y.; Li, Y.; Fu, K.; Feng, R. Associations between Dietary Nutrient Intakes and Hepatic Lipid Contents in NAFLD Patients Quantified by (1)H-MRS and Dual-Echo MRI. Nutrients 2016, 8, 527. [CrossRef] [PubMed]

46. Kobayashi, Y.; Tatsumi, H.; Hattori, M.; Sugiyama, H.; Wada, S.; Kuwahata, M.; Tanaka, S.; Kanemasa, K.; Sumida, Y.; Naito, Y.; et al. Comparisons of dietary intake in Japanese with non-alcoholic fatty liver disease and type 2 diabetes mellitus. J. Clin. Biochem. Nutr. 2016, 59, 215-219. [CrossRef] [PubMed]

47. Song, Y.; Manson, J.E.; Buring, J.E.; Liu, S. A prospective study of red meat consumption and type 2 diabetes in middle-aged and elderly women: The women's health study. Diabetes Care 2004, 27, 2108-2115. [CrossRef] [PubMed]

48. Shi, L.; Liu, Z.W.; Li, Y.; Gong, C.; Zhang, H.; Song, L.J.; Huang, C.Y.; Li, M. The prevalence of nonalcoholic fatty liver disease and its association with lifestyle/dietary habits among university faculty and staff in Chengdu. Biomed. Environ. Sci. 2012, 25, 383-391. [CrossRef] [PubMed]

49. Collison, K.S.; Maqbool, Z.; Saleh, S.M.; Inglis, A.; Makhoul, N.J.; Bakheet, R.; Al-Johi, M.; Al-Rabiah, R.; Zaidi, M.Z.; Al-Mohanna, F.A. Effect of dietary monosodium glutamate on trans fat-induced nonalcoholic fatty liver disease. J. Lipid Res. 2009, 50, 1521-1537. [CrossRef] [PubMed]

50. Da Silva, H.E.; Arendt, B.M.; Noureldin, S.A.; Therapondos, G.; Guindi, M.; Allard, J.P. A cross-sectional study assessing dietary intake and physical activity in Canadian patients with nonalcoholic fatty liver disease vs. healthy controls. J. Acad. Nutr. Diet. 2014, 114, 1181-1194. [CrossRef] [PubMed]

51. Cordain, L.; Eaton, S.B.; Sebastian, A.; Mann, N.; Lindeberg, S.; Watkins, B.A.; O'Keefe, J.H.; Brand-Miller, J. Origins and evolution of the Western diet: Health implications for the 21st century. Am. J. Clin. Nutr. 2005, 81, 341-354. [PubMed]

52. Schulze, M.B.; Manson, J.E.; Willett, W.C.; Hu, F.B. Processed meat intake and incidence of Type 2 diabetes in younger and middle-aged women. Diabetologia 2003, 46, 1465-1473. [CrossRef] [PubMed]

53. De Castro, G.S.; Calder, P.C. Non-alcoholic fatty liver disease and its treatment with $n-3$ polyunsaturated fatty acids. Clin. Nutr. 2017. [CrossRef] [PubMed]

54. Araya, J.; Rodrigo, R.; Videla, L.A.; Thielemann, L.; Orellana, M.; Pettinelli, P.; Poniachik, J. Increase in long-chain polyunsaturated fatty acid $n-6 / n-3$ ratio in relation to hepatic steatosis in patients with non-alcoholic fatty liver disease. Clin. Sci. (Lond.) 2004, 106, 635-643. [CrossRef] [PubMed]

55. Kishino, T.; Ohnishi, H.; Ohtsuka, K.; Matsushima, S.; Urata, T.; Watanebe, K.; Honda, Y.; Mine, Y.; Matsumoto, M.; Nishikawa, K.; et al. Low concentrations of serum n-3 polyunsaturated fatty acids in non-alcoholic fatty liver disease patients with liver injury. Clin. Chem. Lab. Med. 2011, 49, 159-162. [CrossRef] [PubMed]

56. Zheng, J.-S.; Xu, A.; Huang, T.; Yu, X.; Li, D. Low docosahexaenoic acid content in plasma phospholipids is associated with increased non-alcoholic fatty liver disease in China. Lipids 2012, 47, 549-556. [CrossRef] [PubMed]

57. Marchesini, G.; Petta, S.; Dalle Grave, R. Diet, weight loss, and liver health in nonalcoholic fatty liver disease: Pathophysiology, evidence, and practice. Hepatology 2016, 63, 2032-2043. [CrossRef] [PubMed]

58. Cave, M.; Deaciuc, I.; Mendez, C.; Song, Z.; Joshi-Barve, S.; Barve, S.; McClain, C. Nonalcoholic fatty liver disease: Predisposing factors and the role of nutrition. J. Nutr. Biochem. 2007, 18, 184-195. [CrossRef] [PubMed]

59. Buckland, G.; Bach, A.; Serra-Majem, L. Obesity and the Mediterranean diet: A systematic review of observational and intervention studies. Obes. Rev. 2008, 9, 582-593. [CrossRef] [PubMed] 
60. Sofi, F.; Cesari, F.; Abbate, R.; Gensini, G.F.; Casini, A. Adherence to Mediterranean diet and health status: Meta-analysis. BMJ 2008, 337, a1344. [CrossRef] [PubMed]

61. Kontogianni, M.D.; Tileli, N.; Margariti, A.; Georgoulis, M.; Deutsch, M.; Tiniakos, D.; Fragopoulou, E.; Zafiropoulou, R.; Manios, Y.; Papatheodoridis, G. Adherence to the Mediterranean diet is associated with the severity of non-alcoholic fatty liver disease. Clin. Nutr. 2014, 33, 678-683. [CrossRef] [PubMed]

62. Abenavoli, L.; Milic, N.; Peta, V.; Alfieri, F.; De Lorenzo, A.; Bellentani, S. Alimentary regimen in non-alcoholic fatty liver disease: Mediterranean diet. World J. Gastroenterol. 2014, 20, 16831-16840. [CrossRef] [PubMed]

63. Bozzetto, L.; Prinster, A.; Annuzzi, G.; Costagliola, L.; Mangione, A.; Vitelli, A.; Mazzarella, R.; Longobardo, M.; Mancini, M.; Vigorito, C.; et al. Liver fat is reduced by an isoenergetic MUFA diet in a controlled randomized study in type 2 diabetic patients. Diabetes Care 2012, 35, 1429-1435. [CrossRef] [PubMed]

64. Ryan, M.C.; Itsiopoulos, C.; Thodis, T.; Ward, G.; Trost, N.; Hofferberth, S.; O’Dea, K.; Desmond, P.V.; Johnson, N.A.; Wilson, A.M. The Mediterranean diet improves hepatic steatosis and insulin sensitivity in individuals with non-alcoholic fatty liver disease. J. Hepatol. 2013, 59, 138-143. [CrossRef] [PubMed]

65. Zelber-Sagi, S.; Salomone, F.; Mlynarsky, L. The Mediterranean dietary pattern as the diet of choice for non-alcoholic fatty liver disease: Evidence and plausible mechanisms. Liver Int. 2017, 37, 936-949. [CrossRef] [PubMed]

66. Lopez-Miranda, J.; Perez-Jimenez, F.; Ros, E.; De Caterina, R.; Badimon, L.; Covas, M.I.; Escrich, E.; Ordovas, J.M.; Soriguer, F.; Abia, R.; et al. Olive oil and health: Summary of the II international conference on olive oil and health consensus report, Jaen and Cordoba (Spain) 2008. Nutr. Metab. Cardiovasc. Dis. 2010, 20, 284-294. [CrossRef] [PubMed]

67. Salomone, F.; Godos, J.; Zelber-Sagi, S. Natural antioxidants for non-alcoholic fatty liver disease: Molecular targets and clinical perspectives. Liver Int. 2016, 36, 5-20. [CrossRef] [PubMed]

68. Federico, A.; Dallio, M.; Godos, J.; Loguercio, C.; Salomone, F. Targeting gut-liver axis for the treatment of nonalcoholic steatohepatitis: Translational and clinical evidence. Transl. Res. 2016, 167, 116-124. [CrossRef] [PubMed]

69. Sacks, F.M.; Svetkey, L.P.; Vollmer, W.M.; Appel, L.J.; Bray, G.A.; Harsha, D.; Obarzanek, E.; Conlin, P.R.; Miller, E.R., 3rd; Simons-Morton, D.G.; et al. Effects on blood pressure of reduced dietary sodium and the Dietary Approaches to Stop Hypertension (DASH) diet. DASH-Sodium Collaborative Research Group. N. Engl. J. Med. 2001, 344, 3-10. [CrossRef] [PubMed]

70. Zivkovic, A.M.; German, J.B.; Sanyal, A.J. Comparative review of diets for the metabolic syndrome: Implications for nonalcoholic fatty liver disease. Am. J. Clin. Nutr. 2007, 86, 285-300. [PubMed]

71. Liese, A.D.; Nichols, M.; Sun, X.; D'Agostino, R.B.J.; Haffner, S.M. Adherence to the DASH Diet is inversely associated with incidence of type 2 diabetes: The insulin resistance atherosclerosis study. Diabetes Care 2009, 32, 1434-1436. [CrossRef] [PubMed]

72. Fung, T.T.; Chiuve, S.E.; McCullough, M.L.; Rexrode, K.M.; Logroscino, G.; Hu, F.B. Adherence to a DASH-style diet and risk of coronary heart disease and stroke in women. Arch. Intern. Med. 2008, 168, 713-720. [CrossRef] [PubMed]

73. Hekmatdoost, A.; Shamsipour, A.; Meibodi, M.; Gheibizadeh, N.; Eslamparast, T.; Poustchi, H. Adherence to the Dietary Approaches to Stop Hypertension (DASH) and risk of Nonalcoholic Fatty Liver Disease. Int. J. Food Sci. Nutr. 2016, 67, 1024-1029. [CrossRef] [PubMed]

74. Razavi Zade, M.; Telkabadi, M.H.; Bahmani, F.; Salehi, B.; Farshbaf, S.; Asemi, Z. The effects of DASH diet on weight loss and metabolic status in adults with non-alcoholic fatty liver disease: A randomized clinical trial. Liver Int. 2016, 36, 563-571. [CrossRef] [PubMed]

75. John, J.H.; Ziebland, S.; Yudkin, P.; Roe, L.S.; Neil, H.A.W. Effects of fruit and vegetable consumption on plasma antioxidant concentrations and blood pressure: A randomised controlled trial. Lancet 2002, 359, 1969-1974. [CrossRef]

76. Ross, A.B.; Godin, J.-P.; Minehira, K.; Kirwan, J.P. Increasing whole grain intake as part of prevention and treatment of nonalcoholic Fatty liver disease. Int. J. Endocrinol. 2013, 2013, 585876. [CrossRef] [PubMed]

77. Gupta, V.; Mah, X.-J.; Garcia, M.C.; Antonypillai, C.; van der Poorten, D. Oily fish, coffee and walnuts: Dietary treatment for nonalcoholic fatty liver disease. World J. Gastroenterol. 2015, 21, 10621-10635. [CrossRef] [PubMed] 
78. Rippe, J.M.; Angelopoulos, T.J. Sugars, obesity, and cardiovascular disease: Results from recent randomized control trials. Eur. J. Nutr. 2016, 55, 45-53. [CrossRef] [PubMed]

79. Pikilidou, M.I.; Lasaridis, A.N.; Sarafidis, P.A.; Befani, C.D.; Koliakos, G.G.; Tziolas, I.M.; Kazakos, K.A.; Yovos, J.G.; Nilsson, P.M. Insulin sensitivity increase after calcium supplementation and change in intraplatelet calcium and sodium-hydrogen exchange in hypertensive patients with Type 2 diabetes. Diabet. Med. 2009, 26, 211-219. [CrossRef] [PubMed]

80. Almoznino-Sarafian, D.; Berman, S.; Mor, A.; Shteinshnaider, M.; Gorelik, O.; Tzur, I.; Alon, I.; Modai, D.; Cohen, N. Magnesium and C-reactive protein in heart failure: An anti-inflammatory effect of magnesium administration? Eur. J. Nutr. 2007, 46, 230-237. [CrossRef] [PubMed]

81. Lopes, H.F.; Martin, K.L.; Nashar, K.; Morrow, J.D.; Goodfriend, T.L.; Egan, B.M. DASH diet lowers blood pressure and lipid-induced oxidative stress in obesity. Hypertension 2003, 41, 422-430. [CrossRef] [PubMed]

82. Roberfroid, M.; Gibson, G.R.; Hoyles, L.; McCartney, A.L.; Rastall, R.; Rowland, I.; Wolvers, D.; Watzl, B.; Szajewska, H.; Stahl, B.; et al. Prebiotic effects: Metabolic and health benefits. Br. J. Nutr. 2010, 104 (Suppl. 2), S1-S63. [CrossRef] [PubMed]

83. Beylot, M. Effects of inulin-type fructans on lipid metabolism in man and in animal models. Br. J. Nutr. 2005, 93 (Suppl. 1), S163-S168. [CrossRef] [PubMed]

84. Parnell, J.A.; Reimer, R.A. Weight loss during oligofructose supplementation is associated with decreased ghrelin and increased peptide YY in overweight and obese adults. Am. J. Clin. Nutr. 2009, 89, 1751-1759. [CrossRef] [PubMed]

85. Daubioul, C.A.; Horsmans, Y.; Lambert, P.; Danse, E.; Delzenne, N.M. Effects of oligofructose on glucose and lipid metabolism in patients with nonalcoholic steatohepatitis: Results of a pilot study. Eur. J. Clin. Nutr. 2005, 59, 723-726. [CrossRef] [PubMed]

86. Calder, P.C. Very long chain omega-3 (n-3) fatty acids and human health. Eur. J. Lipid Sci. Technol. 2014, 116, 1280-1300. [CrossRef]

87. Scorletti, E.; Byrne, C.D. Omega-3 fatty acids, hepatic lipid metabolism, and nonalcoholic fatty liver disease. Annu. Rev. Nutr. 2013, 33, 231-248. [CrossRef] [PubMed]

88. Capanni, M.; Calella, F.; Biagini, M.R.; Genise, S.; Raimondi, L.; Bedogni, G.; Svegliati-Baroni, G.; Sofi, F.; Milani, S.; Abbate, R.; et al. Prolonged n-3 polyunsaturated fatty acid supplementation ameliorates hepatic steatosis in patients with non-alcoholic fatty liver disease: A pilot study. Aliment. Pharmacol. Ther. 2006, 23, 1143-1151. [CrossRef] [PubMed]

89. Spadaro, L.; Magliocco, O.; Spampinato, D.; Piro, S.; Oliveri, C.; Alagona, C.; Papa, G.; Rabuazzo, A.M.; Purrello, F. Effects of $n-3$ polyunsaturated fatty acids in subjects with nonalcoholic fatty liver disease. Dig. Liver Dis. 2008, 40, 194-199. [CrossRef] [PubMed]

90. Zhu, F.-S.; Liu, S.; Chen, X.-M.; Huang, Z.-G.; Zhang, D.-W. Effects of $n-3$ polyunsaturated fatty acids from seal oils on nonalcoholic fatty liver disease associated with hyperlipidemia. World J. Gastroenterol. 2008, 14, 6395-6400. [CrossRef] [PubMed]

91. Sanyal, A.J.; Abdelmalek, M.F.; Suzuki, A.; Cummings, O.W.; Chojkier, M. No significant effects of ethyl-eicosapentanoic acid on histologic features of nonalcoholic steatohepatitis in a phase 2 trial. Gastroenterology 2014, 147, 377.el-384.e1. [CrossRef] [PubMed]

92. Nogueira, M.A.; Oliveira, C.P.; Ferreira Alves, V.A.; Stefano, J.T.; Rodrigues, L.S.D.R.; Torrinhas, R.S.; Cogliati, B.; Barbeiro, H.; Carrilho, F.J.; Waitzberg, D.L. Omega-3 polyunsaturated fatty acids in treating non-alcoholic steatohepatitis: A randomized, double-blind, placebo-controlled trial. Clin. Nutr. 2016, 35, 578-586. [CrossRef] [PubMed]

93. Yari, Z.; Rahimlou, M.; Eslamparast, T.; Ebrahimi-Daryani, N.; Poustchi, H.; Hekmatdoost, A. Flaxseed supplementation in non-alcoholic fatty liver disease: A pilot randomized, open labeled, controlled study. Int. J. Food Sci. Nutr. 2016, 67, 461-469. [CrossRef] [PubMed]

94. Browning, J.D.; Baker, J.A.; Rogers, T.; Davis, J.; Satapati, S.; Burgess, S.C. Short-term weight loss and hepatic triglyceride reduction: Evidence of a metabolic advantage with dietary carbohydrate restriction. Am. J. Clin. Nutr. 2011, 93, 1048-1052. [CrossRef] [PubMed] 
95. Kirk, E.; Reeds, D.N.; Finck, B.N.; Mayurranjan, S.M.; Patterson, B.W.; Klein, S. Dietary fat and carbohydrates differentially alter insulin sensitivity during caloric restriction. Gastroenterology 2009, 136, 1552-1560. [CrossRef] [PubMed]

96. Haufe, S.; Engeli, S.; Kast, P.; Bohnke, J.; Utz, W.; Haas, V.; Hermsdorf, M.; Mahler, A.; Wiesner, S.; Birkenfeld, A.L.; et al. Randomized comparison of reduced fat and reduced carbohydrate hypocaloric diets on intrahepatic fat in overweight and obese human subjects. Hepatology 2011, 53, 1504-1514. [CrossRef] [PubMed]

97. Tendler, D.; Lin, S.; Yancy, W.S.J.; Mavropoulos, J.; Sylvestre, P.; Rockey, D.C.; Westman, E.C. The effect of a low-carbohydrate, ketogenic diet on nonalcoholic fatty liver disease: A pilot study. Dig. Dis. Sci. 2007, 52, 589-593. [CrossRef] [PubMed]

98. De Luis, D.A.; Aller, R.; Izaola, O.; Gonzalez Sagrado, M.; Conde, R. Effect of two different hypocaloric diets in transaminases and insulin resistance in nonalcoholic fatty liver disease and obese patients. Nutr. Hosp. 2010, 25, 730-735. [PubMed]

99. Katsagoni, C.N.; Georgoulis, M.; Papatheodoridis, G.V.; Panagiotakos, D.B.; Kontogianni, M.D. Effects of lifestyle interventions on clinical characteristics of patients with non-alcoholic fatty liver disease: A meta-analysis. Metabolism 2017, 68, 119-132. [CrossRef] [PubMed]

100. Velayudham, A.; Dolganiuc, A.; Ellis, M.; Petrasek, J.; Kodys, K.; Mandrekar, P.; Szabo, G. VSL\#3 probiotic treatment attenuates fibrosis without changes in steatohepatitis in a diet-induced nonalcoholic steatohepatitis model in mice. Hepatology 2009, 49, 989-997. [CrossRef] [PubMed]

101. Wong, V.W.-S.; Won, G.L.-H.; Chim, A.M.-L.; Chu, W.C.-W.; Yeung, D.K.-W.; Li, K.C.-T.; Chan, H.L.-Y. Treatment of nonalcoholic steatohepatitis with probiotics. A proof-of-concept study. Ann. Hepatol. 2013, 12, 256-262. [PubMed]

102. Argo, C.K.; Patrie, J.T.; Lackner, C.; Henry, T.D.; de Lange, E.E.; Weltman, A.L.; Shah, N.L.; Al-Osaimi, A.M.; Pramoonjago, P.; Jayakumar, S.; et al. Effects of $n-3$ fish oil on metabolic and histological parameters in NASH: A double-blind, randomized, placebo-controlled trial. J. Hepatol. 2015, 62, 190-197. [CrossRef] [PubMed]

103. Nabavi, S.; Rafraf, M.; Somi, M.H.; Homayouni-Rad, A.; Asghari-Jafarabadi, M. Effects of probiotic yogurt consumption on metabolic factors in individuals with nonalcoholic fatty liver disease. J. Dairy Sci. 2014, 97, 7386-7393. [CrossRef] [PubMed]

104. Trovato, F.M.; Catalano, D.; Martines, G.F.; Pace, P.; Trovato, G.M. Mediterranean diet and non-alcoholic fatty liver disease: The need of extended and comprehensive interventions. Clin. Nutr. 2015, 34, 86-88. [CrossRef] [PubMed]

105. Abenavoli, L.; Greco, M.; Nazionale, I.; Peta, V.; Milic, N.; Accattato, F.; Foti, D.; Gulletta, E.; Luzza, F. Effects of Mediterranean diet supplemented with silybin-vitamin E-phospholipid complex in overweight patients with non-alcoholic fatty liver disease. Expert Rev. Gastroenterol. Hepatol. 2015, 9, 519-527. [CrossRef] [PubMed]

106. Hatzitolios, A.; Savopoulos, C.; Lazaraki, G.; Sidiropoulos, I.; Haritanti, P.; Lefkopoulos, A.; Karagiannopoulou, G.; Tzioufa, V.; Dimitrios, K. Efficacy of omega-3 fatty acids, atorvastatin and orlistat in non-alcoholic fatty liver disease with dyslipidemia. Indian J. Gastroenterol. 2004, 23, 131-134. [PubMed]

107. Tanaka, N.; Sano, K.; Horiuchi, A.; Tanaka, E.; Kiyosawa, K.; Aoyama, T. Highly purified eicosapentaenoic acid treatment improves nonalcoholic steatohepatitis. J. Clin. Gastroenterol. 2008, 42, 413-418. [CrossRef] [PubMed]

108. Vega, G.L.; Chandalia, M.; Szczepaniak, L.S.; Grundy, S.M. Effects of N-3 fatty acids on hepatic triglyceride content in humans. J. Investig. Med. 2008, 56, 780-785. [CrossRef] [PubMed]

109. Scorletti, E.; Bhatia, L.; McCormick, K.G.; Clough, G.F.; Nash, K.; Calder, P.C.; Byrne, C.D. Design and rationale of the WELCOME trial: A randomised, placebo controlled study to test the efficacy of purified long chainomega-3 fatty acid treatment in non-alcoholic fatty liver disease [corrected]. Contemp. Clin. Trials 2014, 37, 301-311. [CrossRef] [PubMed]

110. Dasarathy, S.; Dasarathy, J.; Khiyami, A.; Yerian, L.; Hawkins, C.; Sargent, R.; McCullough, A.J. Double-blind randomized placebo-controlled clinical trial of omega 3 fatty acids for the treatment of diabetic patients with nonalcoholic steatohepatitis. J. Clin. Gastroenterol. 2015, 49, 137-144. [CrossRef] [PubMed] 
111. Li, Y.-H.; Yang, L.-H.; Sha, K.-H.; Liu, T.-G.; Zhang, L.-G.; Liu, X.-X. Efficacy of poly-unsaturated fatty acid therapy on patients with nonalcoholic steatohepatitis. World J. Gastroenterol. 2015, 21, 7008-7013. [CrossRef] [PubMed]

112. Petersen, K.F.; Dufour, S.; Befroy, D.; Lehrke, M.; Hendler, R.E.; Shulman, G.I. Reversal of nonalcoholic hepatic steatosis, hepatic insulin resistance, and hyperglycemia by moderate weight reduction in patients with type 2 diabetes. Diabetes 2005, 54, 603-608. [CrossRef] [PubMed]

(C) 2017 by the authors. Licensee MDPI, Basel, Switzerland. This article is an open access article distributed under the terms and conditions of the Creative Commons Attribution (CC BY) license (http:/ / creativecommons.org/licenses/by/4.0/). 